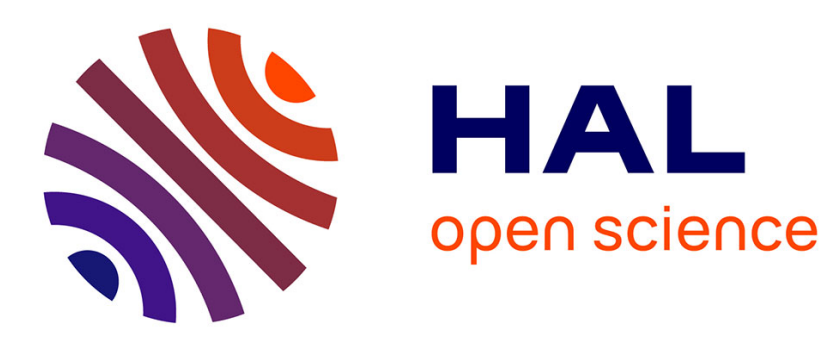

\title{
Heterogeneity in Price Rigidity: Evidence from a Case Study Using Micro-Level Data
}

Daniel Levy, Shantanu Dutta, Mark Bergen

\section{To cite this version:}

Daniel Levy, Shantanu Dutta, Mark Bergen. Heterogeneity in Price Rigidity: Evidence from a Case Study Using Micro-Level Data. Journal of Money, Credit, and Banking, 2002, 34 (1), pp.197-220. 10.1353/mcb.2002.0031 . hal-02386496

\section{HAL Id: hal-02386496 https://hal.science/hal-02386496}

Submitted on 29 Nov 2019

HAL is a multi-disciplinary open access archive for the deposit and dissemination of scientific research documents, whether they are published or not. The documents may come from teaching and research institutions in France or abroad, or from public or private research centers.
L'archive ouverte pluridisciplinaire HAL, est destinée au dépôt et à la diffusion de documents scientifiques de niveau recherche, publiés ou non, émanant des établissements d'enseignement et de recherche français ou étrangers, des laboratoires publics ou privés. 


\title{
Heterogeneity in Price Rigidity: Evidence from a Case Study Using Micro-Level Data
}

\author{
Daniel Levy* \\ Department of Economics, Bar-Ilan University \\ Ramat-Gan 52900, ISRAEL \\ Tel: (972) 3-531-8331, Fax: (972) 3-535-3180 \\ Levyda@mail.biu.ac.il \\ and \\ Department of Economics, Emory University \\ Atlanta GA 30322-2240 \\ Tel: (404) 727-2941, Fax: (404) 727-4639 \\ ECONDL@emory.edu
}

\author{
Shantanu Dutta \\ School of Business Administration, University of Southern California \\ Los Angeles, CA 90089-1421 \\ (213) 740-5038, sdutta@marshall.usc.edu
}

\author{
Mark Bergen \\ Department of Logistics and Marketing Management, University of Minnesota \\ Minneapolis, MN 55455 \\ (612) 624-1821, mbergen@csom.umn.edu
}

JEL Codes: E12, E31, L16

Last Revision: November 12, 2000

\begin{abstract}
The authors thank two anonymous referees, and John Leahy and Alan Stockman, the discussants at the April 1997 NBER Monetary Economics Program Meeting and at the 1997 American Economic Association Meetings, respectively, for providing thoughtful comments and suggestions. They also thank the late Peter Aranson, Laurence Ball, Robert Barsky, Susanto Basu, Stephen Cecchetti, Robert Chirinko, Hashem Dezhbakhsh, Paul Geroski, Steve Hoch, James Holmes, Abel Jeuland, Anil Kashyap, Evan Koenig, Greg Mankiw, Fred McChesney, Georg Müller, Allan Meltzer, Sam Peltzman, Carol Simon, Ruey Tsay, Harald Uhlig, Ken West, Tao Zha, and the seminar participants at the University of Chicago and Emory University for comments and suggestions. In addition, they thank numerous individuals from the Florida Department of Citrus, University of Florida Center for Citrus Research and Education, the Florida Agricultural Statistics Service, and Produce Manufacturing Association, including John Attaway, Sandy Barros, Carolyn Brown, Steve Irvin, Ed Moor, Ron Muraro, Bill Stinson, and Lola VanGilst, for help and for providing some of the data. The authors are grateful to Michael Caldwell, Matt Higgins, and Yihong Xia for research assistance. Helmut Lütkepohl kindly provided a Gauss program for doing the estimations performed for this paper. Finally, they thank the University of Chicago for financial support and a Mid-western retail supermarket chain for providing access to their database. The first author has received a financial support also from Bar-Ilan University where he was a Visiting Associate Professor when this paper was completed. All authors contributed equally. The usual disclaimer applies.
\end{abstract}

\footnotetext{
* Corresponding author.
} 


\title{
Heterogeneity in Price Rigidity: Evidence from a Case Study Using Micro-Level Data
}

\begin{abstract}
We combine two datasets to study price rigidity. The first consists of weekly time series of retail, wholesale, and spot prices for twelve products. These time series contain two exogenous cost shocks. We find that prices exhibit more rigidity in response to the second shock than the first. The second dataset consists of all publicly available information about the shocks. Content analysis of these information reveals that the first shock is larger and more persistent, and the market has more information on it than the second. We conclude, therefore, that prices are more flexible in response to cost shocks that are larger, that are more persistent, and on which market participants have more information
\end{abstract}




\section{Introduction}

Variation in price rigidity is an issue of considerable interest in macroeconomics because understanding its reasons may shed light on causes of price rigidity. ${ }^{1}$ For example, according to Gordon (1981, p. 517), understanding it “... is crucial for the theory of price adjustment." Caplin (1993, p. 21) describes it as unfortunate “... that so little attention has been given to characterizing the circumstances that give rise to high and low levels of nominal price inertia. Progress in this dimension calls for more detailed empirical work and for increased understanding of the manner in which corporations actually arrive at pricing decisions." Weiss (1993, p. 15) also suggests to include all "... relevant information at the level of the firm, including costs and demand data." Similarly, Lach and Tsiddon (1992, p. 351) suggest to use actual transaction prices to study price rigidity because they "... most closely resemble the data envisioned by the cost of adjustment theory: price quotations at the level of the price setter." Unfortunately, only a handful of studies use actual transaction prices to study price rigidity (Kashyap, 1995, and Genesove, 1999).

We combine two unique data sets to create a micro level case-study of time-varying price rigidity. The first data set consists of weekly retail, wholesale, and commodity prices for twelve orange juice products which are categorized as either refrigerated or frozen. A unique feature of this data set is that it contains two episodes of exogenous commodity cost shocks. The cost-price data suggest that manufacturers' and retailer's reactions to the shocks were different. Specifically, we find that prices exhibit significantly more rigidity in response to the second shock than the first.

To explain this variation in price rigidity we collected a second data set consisting of all public information on the cost shocks. Because it is difficult to know what information economic agents have and use, macroeconomists usually are forced to make assumptions of various kinds about the content of this information. For example, many empirical macroeconomic studies that make use of anticipated/unanticipated series rely on forecast generating equations to generate these series. We, in contrast, study a very specific product market where determination of the relevant information set is less ambiguous in comparison to studies that use aggregate data. Thus, we collected all publicly available information we could find about the causes and effects of the cost shocks, and by analyzing the content of these information, we are able to assess the extent of the actual information the orange juice market participants likely had. We shall also note the novelty of the method we use to identify shock persistence. In macroeconomics, identification of temporary and permanent components of 
shocks is usually accomplished by econometric means. The reason for this practice is that it is difficult to know how market participants assess economic variables' persistence. We are able to overcome this difficulty by focusing on specific cost shocks and by studying in detail their actual causes and effects and the events surrounding them, we are able to evaluate their likely permanence.

We find that (i) the first cost shock was larger than the second, (ii) the first shock was more persistent than the second, and (iii) the market had more information on the first shock than the second. These findings, therefore, suggest that prices are more flexible in response to cost shocks that are larger in size, more persistent, and on which the market participants have more information. This conclusion is particularly valuable because the nature of the price rigidity we are documenting, enable us to control for various market features that are frequently used to explain variation in price rigidity. For example, over the three-year sample period, the market structure and industry concentration, the nature of long term relationships, contractual arrangements, and the number of stages of processing, all have remained unchanged. Further, orange juice products have a constant quality. The variation in price rigidity we document in this paper, therefore, cannot be explained by variation in any one of these factors.

The paper is organized as follows. In section 2, we describe the data. In section 3, we analyse the retailer's and manufacturers' reactions to the two cost shocks. In section 4, we compare the cost shocks. In section 5, we conclude by discussing the findings in the context of existing price rigidity theories. In the appendix we list the information collected and their sources.

\section{Data}

\section{Cost-Price Data}

The first data set consists of 168 weekly observations (September 7, 1989-November 19, 1992) of actual retail, wholesale, and commodity spot prices for twelve Florida orange juice products. We have data for three brands, Tropicana, Minute Maid, and the Store Brand (in-house supermarket brand). Each brand comes in two forms, frozen concentrated and reconstituted from frozen concentrate (refrigerated), and two sizes: the frozen concentrated orange juice comes in $12 \mathrm{oz}$ and $16 \mathrm{oz}$ cans while refrigerated juice comes in $64 \mathrm{oz}$ and $96 \mathrm{oz}$ ( $128 \mathrm{oz}$ for the Store Brand) containers. In the analysis that follows we focus on two representative products, one frozen concentrated orange juice (Store Brand, 12oz, displayed on Figure 1) and the other, refrigerated orange juice (Tropicana brand, 96oz, displayed on Figure 2). The remaining ten products exhibit similar behavior but are not discussed to save space. ${ }^{2}$

Chart 1 displays a general description of the frozen concentrated orange juice market, which provides about 70 percent of the orange juice sold in the U.S. The chart indicates that this market 
consists of two channels: the retail channel, which represents the final goods market, and the wholesale channel, which represents the intermediate goods market. Thus, the market we study is characterized by a hierarchical structure, similar to the "stages of processing" structure studied by Blanchard (1983). ${ }^{3}$

The data set has several unique features. First, it consists of actual retail and wholesale transaction prices and a measure of upstream commodity cost. The retail and wholesale prices come from the supermarket scanner. While scanner data are rarely used by economists, they have been extensively used in marketing to study such issues as consumer choice behavior (Kamakura and Russell, 1989, and Gonul and Srinivasan 1993), brand choice (Allenby and Rossi 1991; Chintagunta et al., 1991; and Villas-Boas and Winer, 1999), pricing strategy (Raju, et al., 1995), etc.

This chain changes prices once a week on a chain-wide basis, and we have chosen a representative store from the Chicago area. ${ }^{4}$ The wholesale prices are what the retailer pays the orange juice manufacturer, and is the cost measure the retailer uses in pricing decisions. Having access to the actual cost data is unique given that they are proprietary and rarely available. Further, having access to both actual price and actual cost data, enables us to consider a richer notion of price rigidity, following the works of Cecchetti (1986), Hannan and Berger (1991), Neumark and Sharpe (1993), Kashyap (1995), and Slade (1996a, 1996b). According to this notion, prices are rigid if they do not respond to changes in cost or demand conditions. Due to the lack of cost data, many studies measure price rigidity indirectly, using price change frequency, time span between price changes, etc. Having both series for the same products enable us to study this broader notion of price rigidity.

As a measure of manufacturers' costs we construct spot market prices from the nearest futures contract price of frozen concentrated orange juice from the New York Cotton Exchange by adjusting it for storage and carrying cost using a cash-and-carry formula. ${ }^{5}$ Deviations of the contract price from the spot price merely represent capital gains and losses to the buyer/seller. Thus, the spot price reflects the market and weather conditions fairly well and, therefore, is a reasonable proxy for manufacturers' costs.

The cost-price data have additional advantages. First, we control for various market features. For example, over the three year period, market structure and industry concentration, the nature of long term relationships, contractual arrangements, and the number of stages of processing, all have remained unchanged. Therefore, the price rigidity variation we find cannot be explained by any of them. Second, orange juice products have a constant quality, monitored by the Florida Department of Citrus and the United States Department of Agriculture, who set limits on the amount of sinking solids; the frozen concentrated orange juice needs also to pass a test which guarantees no gel pulp is left after 
reconstitution. Also, both frozen concentrated orange juice and refrigerated orange juice must have a minimum Brix content.

Third, we examine the effect of exogenous cost changes on prices. Retail costs are exogenous with respect to retail price because: (i) the orange juice market has a hierarchical structure as the retailer follows the manufacturers in the channel of distribution; (ii) the manufacturers sell nationally, while the retailer is one of many local sellers; and (iii) as an orange juice seller, the retailer is significantly smaller than any one of the manufacturers. Similarly, the spot cost is exogenous with respect to the wholesale and retail prices (Roll, 1984; and Baur and Orazem, 1994). Further, we explain variation in prices using costs, as it is done in pass-through literature (Borenstein, et al., 1992), following Roll's (1984) finding that most of the orange juice price volatility is due to supply shocks. Further, we found no evidence of demand changes in trade publications. ${ }^{6}$ The studies conducted by Florida Citrus Commission and University of Florida Center for Citrus Research and Education, as well as a recent study by Dutta, Bergen, and Levy (2002), reach similar conclusions. Finally, variation in orange juice demand is unlikely since orange juice is consumed on a weekly basis, similar to milk and bread.

\section{Information Data}

The data in our sample contain two exogenous cost increases. Figure 1, which plots the cost-price series for Store Brand, 12oz, frozen concentrated orange juice, shows the spot cost jumping significantly during the second half of December 1989 (weeks 15-17). Another big jump occurs during the second half of October 1991 (weeks 110-112). ${ }^{7}$ It is the difference in the reaction of manufacturers and retailers to these two cost shocks that comprises the price rigidity variation we document. ${ }^{8}$

To evaluate the extent of these shocks' persistence and the amount of information available about them, we undertook an exhaustive search of all public information sources including local and national newspapers, trade journals, United States Department of Agriculture, local and network TV, CNN, Florida Department of Citrus, Produce Manufacturing Association, University of Florida Center for Citrus Research and Education, and Florida Agricultural Statistics Service. For each shock we looked at all information starting two months before the shock until two months after the prices returned to their original level. The search was done through Lexus/Nexus using key words "FCOJ," "frozen concentrated orange juice," "FCOJ and freeze," "orange," "orange juice," "orange juice and freeze," “citrus," and "beverage." We also contacted the Produce Manufacturing Association which collects various trade information on produce including orange juice. The Produce Manufacturing Association personnel helped us compile all information pertaining to orange juice around the time of the two shocks. 
In addition, we contacted all local TV stations in the Chicago area as well as the networks including CNN. We received information from WGN-Channel 9 and CNN. ${ }^{9}$

After collecting these materials, we analyzed their content. Content Analysis, which is a systematic technique for analyzing a message content, is guided by rules to minimize the possibility that the findings reflect the analyst's subjective predispositions (Holsti, 1969; and Kassarjian, 1977). We had two research assistants independently analyze the contents of all the material collected and summarize their main theme. ${ }^{10}$ The findings reported below are based on consensus between the two researchers. This is a conservative approach since it requires that both researchers agree on the theme of all the reports. In published studies, an $80 \%$ or higher agreement is considered acceptable (Kassarjian, 1977). ${ }^{11}$ Although, there is always a possibility of some bias when it comes to interpretation of the content of some information, we should note that in most cases the interpretation of the news reports we collected were relatively straightforward and necessitated very little subjective judgement because of the factual nature of the information. This factual nature of the information collected also diminished our concern regarding any potential journalistic inaccuracy of the reports themselves. Based on the content analysis of all information collected we conclude that there were some fundamental differences between the two cost shocks in terms of their size, persistence, and information. These findings along with the information collected are described in Section $4 .{ }^{12}$

\section{Retailer's and Manufacturers' Reaction to the Cost Shocks}

\section{Reaction to the First Cost Shock}

Following the initial spot cost shock during the week of December 21, 1989 (week 15), wholesale price increases reach their peak during the week of April 12, 1990 (week 31). ${ }^{13}$ Once the spot cost increases, it remains at that high level for about 24 weeks (weeks 20-44). The wholesale price exhibits a similar pattern, although it remains at the peak level for only 17 weeks, from March 29, 1990 until July 19, 1990. On July 19, 1990, the wholesale price begins a downward adjustment to the commodity spot cost. The adjustment is gradual, and looks slower than the spot cost decrease. It takes the wholesale price over a year from the time it starts to decline (around week 47), until it reaches the pre-shock level (around week 100), while the spot price completes its decline to the pre-shock level by the 58th week. This suggests a possible asymmetry in the orange juice wholesale price adjustment, similar to gasoline prices (Borenstein, et al., 1992) and interest rates (Hannan and Berger, 1991). ${ }^{14}$ 
The retail price response to the wholesale price increase is faster than the response of the wholesale price to the spot cost increase. In fact, the retail price may be increasing faster than the wholesale price during the 20th-28th weeks, suggesting that the retailers may be responding, at least in part, to the spot cost increase. This is clearly possible from informational point of view: the retailers, like other market participants, already had information on the cause and severity of this cost shock several weeks earlier. The retail price increases first to 13.3 cents/oz on week 21 , to 14.1 cents/oz on week 29 , and finally to 14.9 cents/oz on week 49, before starting to decline. The retail price remains at or above 14 cents/oz for almost 36 weeks, but it adjusts downwards, once the adjustment begins, rather quickly. The decrease in the retail price begins on the 64th week, and is fully complete by the 82 nd week. Thus, the retail price adjusts to the wholesale price substantially faster in comparison to the adjustment of the wholesale price to the spot cost. The data, therefore, suggests that the cost shock leads to an increase in the wholesale price and consequently to an increase in the retail price. The upward adjustment of both series seems to be proportional to the size of the cost shock.

\section{Reaction to the Second Cost Shock}

The second shock occurs during the week of October 17, 1991 (110th week). Here the retail price shows no response to the spot cost increase. The wholesale price increases but the increase merely takes the wholesale price back to the level it was at during weeks $98-102$, which is the same level as the prefirst-cost-shock level. The spot price begins declining almost as soon as it increases. The wholesale price, however, does not decline in response to this decrease. This pattern of behavior of the wholesale price suggests that its increase during the 110th week was merely a correction to the over-reaction it experienced during the weeks 98-102. Thus, the data suggest that both the wholesale and the retail price responded to the first cost shock, but they did not respond to the second cost shock. ${ }^{15}$

\section{Differences between the Two Cost Shocks}

The finding that manufacturers' and retailer's responses to upstream cost shocks are more rigid in response to the second cost shock than the first cannot be explained by variation in the nature of long terms relationships, industry concentration, etc., as these factors have not changed during the sample

period. This led us to focus on differences between the two shocks that may explain the findings. ${ }^{16}$ Below we list these differences. In Table 3 we summarize the results. ${ }^{17}$

The Cause of Shocks 
First Cost Shock: The first shock was caused by a freeze. The Florida Department of Citrus (1994) lists it among the nine most "significant Florida Citrus Belt freezes" that occurred since 1957. ${ }^{18}$ The freeze was particularly severe as the temperature dropped to below $25^{\circ} \mathrm{F}$ and stayed there for almost two days. Second Cost Shock: The second shock occurred when the United States Department of Agriculture released a forecast of a lower than expected citrus crop in its October 1991 report. ${ }^{19}$ As stated in the Wall Street Journal (October 14, 1991), "Behind the move was what traders and analysts called a shocking government forecast for a Florida crop of 136 million 90 pound boxes, or $10 \%$ below last year's crop. Industry analysts expected the government to predict the Florida crop would be as much as 10\% bigger than last year." The United States Department of Agriculture report was released on October 12, 1991, after the closing of the New York Cotton Exchange. The spot price increased during the next three trading days followed by smaller increases during the following two weeks.

\section{The Effect on Crops}

First Cost Shock: The freeze destroyed about 20 percent of the trees and a portion of the fruit on trees thereby decreasing the orange crop from 146.6 million boxes to 110.2 million boxes, a decrease of 24.8 percent. The extent of damage can be seen in Table 1 where we report the Florida orange crop, price, and yield estimates. As the table indicates, the output of oranges during the 1989-90 growing season dropped by 24.8 percent in comparison to the 1988-89 season. The severity of the damage can also be seen by looking at the yield figures in terms of boxes/acre: during 1989-90, the yield was down by more than 26 percent and it was accompanied by a 35.5 percent increase in orange prices. Another indicator of the severity of the damage is the gallons/Brix yield reported in Table 2. This is a measure of the solid content of oranges and thus, of the quality of orange crop. According to the table, the United States Department of Agriculture's gallons per Brix yield estimate has dropped from 1.48 in December 1989 to 1.21 in April 1990, which is a 18 percent drop. ${ }^{20}$

Second Cost Shock: Florida orange crop dropped from 151.5 million boxes in the 1990-91 season to 139.8 million boxes in the 1991-1992 season, a decrease of 7.78 percent. The reason for this decline was lower than normal temperatures during January-February and higher than normal temperatures during spring months of 1992 (Florida Agricultural Statistics Service, 1993). As a result, harvest began early because of the early bloom and ended earlier than normal. However, winter lows were above freezing and so no damage to trees or fruit was reported. Therefore, no decline in gallons per Brix yield is observed here. To the contrary, there was a slight increase, 2.7 percent, in this measure of yield. Moreover, according to the November 27, 1992 Report of the CNN's John Zarrella, near perfect 
growing conditions had in the end produced the third largest crop ever of citrus fruits in Florida.

\section{The Effect on Prices}

First Cost Shock: Spot prices increased by $60 \%$ or $\$ 0.0353 /$ oz. After the initial jump, the spot price remained high for over 7 months before it started to decline. A process of increased importation of Brazilian orange juice eventually lead to a gradual reduction in orange juice prices. Brazilian and Mexican orange juice products are often used as a substitute for Florida product in the production of frozen concentrated orange juice. (For example, many frozen concentrated orange juice products produced in the US, have labels which state: "Contains orange juice concentrate from Florida, Mexico, and Brazil.”) At first, the market seemed uncertain about Brazil's ability to meet the demand (see the January 17, 1990 report by the New York Times, "Orange Juice Prices Up on Reports that Brazil May Not Meet Demand."), but according to the officials of the Florida Department of Citrus, these concerns never materialized. Indeed, in a series of articles published later in the year by the New York Times, the paper reported that "Orange juice prices are falling as US predicting big crops" (October 12, 1990), "Orange juice prices collapse to four-year low" (October 13, 1990), and "Orange juice prices down with speculation Brazil would dump frozen concentrate" (October 18, 1990).

Second Cost Shock: Spot prices increased by $36 \%$ or $\$ 0.0211 / \mathrm{oz}$. In contrast to the first shock, the spot price started declining immediately after the jump. This is an indicator of the temporary nature of the second shock, especially in comparison to the first shock.

\section{Media Reports}

First Cost Shock: The first shock, which began with a forecast of extremely cold weather in Florida, was widely documented in newspapers and other print media with 28 mentions between December 1989 and March 1990, and 23 of them talked about extensive damage to the citrus crop and higher orange juice prices. In fact, the Governor of Florida declared the entire state a disaster area and asked for Federal assistance to farmers. Further, we found six TV reports on a local TV channel (WGN-Channel 9, Chicago) and on $\mathrm{CNN}$ and all six mentioned significantly reduced orange crop prospects due to the freeze. Second Cost Shock: From October 1991 to January 1992 there were seventeen reports on this shock and eleven of them said prices were rising. However, over short period of time, the market seems to have revised its forecast of the Florida crop up from the United States Department of Agriculture's level. Further, these reports indicated that the price increase was due to speculative and psychological effects. For instance, the Wall Street Journal (November 7, 1991) reported that “... the cold in North 
Florida is not expected to affect the orange crop but the cold spell is having a psychological effect on the market." All six reports published between January 7, 1992 and January 25, 1992 indicated that commodity prices were actually coming down. The two CNN reports from this period even emphasized the positive prospects of the Florida orange crop. Thus, all printed and TV reports seemed to suggest that this cost shock was of a temporary nature.

\section{Government Reports}

First Cost Shock: This shock was mentioned in five Florida Department of Citrus and United States Department of Agriculture reports. According to the July 12, 1990 United States Department of Agriculture report, the freeze reduced the output as well as the yield. These reports also suggested that commodity prices would go up due to reduced supply.

Second Cost Shock: Florida Department of Citrus and United States Department of Agriculture reports suggested that the lower-than-expected 1991-92 crop (i.e., the forecasted decline in the citrus output) was an aberration and did not change their long-term (i.e., the Florida Department of Citrus' assessment of the Florida citrus output trend over the next 3-5 year horizon) forecast of record crops in the future. In fact, in December 1991, United States Department of Agriculture (Report No. 91/92-3) revised upward its citrus crop estimate for the 1991-92 growing season from 191,195,000 boxes to $198,180,000$ boxes. The actual production for that season turned out to be 208,170,000 boxes (United States Department of Agriculture Citrus Estimate Report No. 92/93-1).

\section{Discussion of the Results and Conclusion}

The findings suggest that (i) prices are more rigid in response to small cost shocks in comparison to large shocks, (ii) prices are more rigid in response to temporary cost shocks in comparison to permanent shocks, ${ }^{21}$ and (iii) prices are more rigid in response to shocks on which there is limited information in comparison to shocks on which there is more information. ${ }^{22}$

The idea that size of a shock may affect price rigidity has been exploited to test the empirical validity of menu cost theories. Under menu costs, firms will adjust to large shocks but not to small shocks. Therefore, large shocks will have a disproportionate effect on prices, which explains a large fraction of movements in postwar U.S. inflation (Ball and Mankiw, 1995). A distinguishing characteristic of our result is that we find it at the level of an individual product using actual transaction prices. 
While some studies suggest the importance of shock persistence for price rigidity (see, for example, McCallum, 1989; Caplin and Leahy, 1991; Sheshinski and Weiss, 1993; and Taylor, 2000), the existing empirical evidence is mostly indirect and rely on aggregate data (see, Meltzer, 1995 for a recent survey). We use a novel method to identify shock persistence. The usual practice is to econometrically identify temporary and permanent components of shocks. The reason for this practice, as Meltzer (1995) indicates, is that it is difficult to know how people assess economic variables' persistence. We are able to overcome this difficulty by focusing on specific cost shocks and by studying in detail their actual causes and effects we evaluate their likely permanence. Our findings at the spot-to-wholesale level are also consistent with Carlton's (1989) suggestion that a firm may not raise price in response to temporary cost increases for fear of loosing customers who may interpret the price increase as permanent. Therefore, the firm will absorb the temporary cost increase.

Macroeconomic importance of imperfect information has long been recognized (Lucas, 1972). ${ }^{23} \mathrm{It}$ is difficult, however, to know what information economic agents really have. Macroeconomists, therefore, are forced to make ad hoc assumptions of various kinds about the content of this information. For example, most of the empirical studies that make use of anticipated or unanticipated series have to rely on forecast generating equations with some autoregressive, autoregressive moving average, or autoregressive-distributed lag structures (Levy, 1990). In contrast, here we study a very micro-level and well-specified product market where determination of the relevant information set is less ambiguous, in comparison to studies that use aggregate level data. Specifically, we collected all the relevant publicly available information we could find about the causes and effects of the shocks, and by analysing the content of these information, we were able to assess the extent of the actual information the orange juice market participants likely had.

The product categories we study are widely used and representative of typical retail items. Also, the pricing practices of the supermarket chain we study are representative of many large U.S. grocery chains. Thus, the market we study is representative of the U.S. grocery industry. However, this is only one case-study. Further, the data only contain two large cost shocks. Therefore, future research should examine price response to cost shocks across other products, retailers, and markets, in order to see whether the results we report generalize to other industries and markets. ${ }^{24}$ 


\section{LITERATURE CITED}

Allenby, Greg M. and Peter E. Rossi. "Quality Perceptions and Asymmetric Switching Between Brands.” Marketing Science 10 (1991), 185-204.

Andersen, Torben. Price Rigidity: Causes and Macroeconomic Implications. Oxford: Clarendon Press, 1994.

Ball, Laurence, and N. Gregory Mankiw. "Relative Price Changes as Aggregate Supply Shocks." Quarterly Journal of Economics 110 (1995), 161-93.

Barsky, Robert, Mark Bergen, Shantanu Dutta, and Daniel Levy. "What Can the Price Gap Between Branded and Generic Tell Us about Markups?" In Scanner Data and Price Indexes, edited by Robert Feenstra and Matthew Shapiro, Chicago: National Bureau of Economic Research and the University of Chicago Press, forthcoming, 2002.

Basu, Susanto. "Intermediate Goods and Business Cycles: Implications for Productivity and Welfare." American Economic Review 85 (1995), 512-531.

Baur, Robert F. and Peter F. Orazem. "The Rationality and Price Effects of United States Department of Agriculture Forecasts of Oranges.” Journal of Finance (1994), 681-695.

Blanchard, Olivier J. "Price Asynchronization and Price-Level Inertia.” In Inflation, Debt, and Indexation, edited by R. Dornbusch and M. Simonsen, pp. 3-24. Cambridge: MIT Press, 1983.

Blinder, Alan S., Elie R.D. Canetti, David E. Lebow, and Jeremy B. Rudd. Asking About Prices: A New Approach to Understanding Price Stickiness. New York: Russell Sage Foundation, 1998.

Borenstein, Severin, A. Colin Cameron, and Richard Gilbert. "Asymmetric Gasoline Price Responses to Crude Oil Price Changes.” Working Paper, UC/Davis (1992).

Brunner, Karl, Alex Cukierman, and Allan H. Meltzer. "Money and Economic Activity, Inventories and Business Cycles." Journal of Monetary Economics 11 (1983), 281-319.

Caplin, Andrew. "Individual Inertia and Aggregate Dynamics." In Optimal Pricing, Inflation, and the Cost of Price Adjustment, edited by Eytan Sheshinski and Yoram Weiss, pp. 19-45. Cambridge, MA: The MIT Press, 1993.

Caplin, Andrew S., and John Leahy. "State Dependent Pricing and the Dynamics of Money and Output.” Quarterly Journal of Economics 106 (1991), 683-708.

Caplin, Andrew and John Leahy. "The Economics of Adjustment." In The Natural Rate of Unemployment, edited by Rod Cross, pp. 77-89. New York, NY: Cambridge University Press, 1995.

Carlson, John A. "Some Evidence on Lump Sum Versus Convex Costs of Changing Prices." Economic Inquiry 30 (1992), 322-331.

Carlton, Dennis W. “The Rigidity of Prices.” American Economic Review 76 (1986), 637-58. 
Carlton, Dennis W. "The Theory and the Facts of How Markets Clear: Is Industrial Organization Valuable for Understanding Macroeconomics?” In Handbook of Industrial Organization, Volume 1, edited by Richard Schmalensee and Robert Willig, pp. 909-946. Amsterdam: North Holland, 1989.

Cecchetti, Stephen G. "The Frequency of Price Adjustment: A Study of the Newsstand Prices of Magazines." Journal of Econometrics 31 (1986), 255-274.

Chen, Haipeng, Mark Bergen, and Daniel Levy. "Consumer Menu Costs and Asymmetry in Small Price Adjustments: Theory and Evidence.” Manuscript, to be presented at the January 2002 Winter Meetings of the Econometric Society Meeting in Atlanta.

Chevalier Judith, Anil K. Kashyap and Peter E. Rossi (2000), "Why Don't Prices Rise During Periods of Peak Demand? Evidence From Scanner Data,” NBER Working Paper, No. 7981.

Chintagunta, P., D. Jain, and N. Vilcassim. "Investigating Heterogeneity in Brand Preferences In Logit Models for Panel Data.” Journal of Marketing Research 28 (1991), 417-428.

Chirinko, Robert S. and Steve M. Fazzari. "Economic Fluctuations, Market Power, and Returns to Scale: Evidence from Firm-Level Data.” Journal of Applied Econometrics 9 (1994), 47-69.

Dutta, Shantanu, Mark Bergen, and Daniel Levy. "Price Flexibility in Channels of Distribution: Evidence from Scanner Data.” Journal of Economic Dynamics and Control, forthcoming, 2002.

Encaoua, David and Paul Geroski. "Price Dynamics and Competition in Five Countries." University of Southampton, Working Paper No. 8414 (1984).

Florida Agricultural Statistics Service. Citrus Summary 1991-92. Orlando: FDACS, 1993.

Florida Agricultural Statistics Service. Citrus Summary 1992-93. Orlando: FDACS, 1994.

Florida Department of Citrus. Florida Citrus Outlook, 1989-90. Orlando: EMRD, 1989.

Florida Department of Citrus. Citrus Reference Book. Orlando: EMRD, 1994.

Genesove, David. "The Nominal Rigidity of Apartment Rents.” National Bureau of Economic Research, Working Paper No. 7137, May, 1999.

Geroski, Paul A. "Price Dynamics in UK Manufacturing: A Microeconomic View." Economica 59 (1992), November, 403-419.

Gonul, Fusun and Kannan Srinivasan. "Modeling Multiple Sources of Heterogeneity in Multinomial Logit Models: Methodological and Managerial Issues.” Marketing Science 12 (1993), 213-229.

Gordon, Robert J. “Output Fluctuations and Gradual Price Adjustment.” Journal of Economic Literature 19 (1981), 493-530.

Gordon, Robert J. "What is New-Keynesian Economics?” Journal of Economic Literature 28 (1990), 1115-1171.

Hannan, Timothy H. and Allen N. Berger. "The Rigidity of Prices: Evidence from the Banking Industry." American Economic Review 81 (1991), 938-945.

Holsti, O. Content Analysis for Social Sciences and Humanities. Reading: Addison-Wesley, 1969. 
Kamakura, Wagner A. and Gary J. Russell. "A Probabilistic Choice Model for Market Segmentation and Elasticity Structure.” Journal of Marketing Research 26 (1989), 379-390.

Kashyap, Anil K. "Sticky Prices: New Evidence from Retail Catalogues." Quarterly Journal of Economics 110 (1995), 245-274.

Kassarjian, Harold H. “Content Analysis in Consumer Research.” Journal of Consumer Research 4 (1977), 8-18.

Lach, Saul, and Daniel Tsiddon. "The Behavior of Prices and Inflation: An Empirical Analysis of Disaggregated Data.” Journal of Political Economy 100 (1992), 349-389.

Levy, Daniel. "Specification and Estimation of Forecast Generating Equations in Models with Rational Expectations." Chapter 3 in Ph.D. Dissertation (1990).

Levy, Daniel, Shantanu Dutta, Mark Bergen, and Robert Venable. "Price Adjustment at Multiproduct Retailers." Managerial and Decision Economics 19 (1998), 81-120.

Levy Daniel, and Andrew T. Young. "The Real Thing: Nominal Rigidity of the Nickel Coke, 1886-1959." Manuscript presented at the January 2001 American Economic Association Meetings.

Liebermann, Yehoshua, and Ben-Zion Zilberfarb. "Price Adjustment Strategy Under Conditions of High Inflation: An Empirical Examination.” Journal of Economics and Business 37 (1985), 253-265.

Lucas, Robert E., "Expectations and Netrality of Money." Journal of Economic Theory 4 (1972), $103-124$.

McCallum, Bennet T. "New Classical Macroeconomics: A Sympathetic Account." Scandinavian Journal of Economics 91 (1989), 223-252.

Meltzer, Allan H. "Information, Sticky Prices, and Macroeconomic Foundations." Federal Reserve Bank of St. Louis Review 77 (1995), 101-118.

Müller, Georg. "Asymmetric Price Responses to Cost Changes: Evidence from the Retail Grocery Industry," Ph.D. Thesis, University of Chicago, 1999.

Neumark, David and Steven Sharpe. "Market Structure and the Nature of Price Rigidity," Quarterly Journal of Economics 108 (1993), 657-680.

Raju, Jagmohan S., Raj K. Sethuraman and Sanjay K. Dhar. "The Introduction and Performance of Store Brands.” Management Science 41 (1995), 957-978.

Roll, Richard. “Orange Juice and Weather,” American Economic Review 74 (1984), 861-880.

Sheshinski, Eytan, and Yoram Weiss. Optimal Pricing, Inflation, and the Cost of Price Adjustment. Cambridge, MA: The MIT Press, 1993.

Slade, Margaret E. "Sticky Prices in a Dynamic Oligopoly: An Investigation of (s, S) Thresholds," March, The University of British Columbia, manuscript, 1996.

Slade, Margaret E. "Optimal Pricing with Costly Adjustment: Evidence from Retail-Grocery Prices." 
Review of Economic Studies 65 (1998), 87-107.

Taylor, John B. "Low Inflation, Pass-Through, and the Pricing Power of Firms." European Economic Review 44 (2000), 1389-1408.

Tse, David K., Russell W. Belk, and Nan Zhou. "Becoming a Consumer Society: A Longitudinal and Cross-Cultural Content Analysis of Print Ads from Hong Kong, the People's Republic of China, and Taiwan," Journal of Consumer Research 15 (1989), 457-472.

Villas-Boas, J. Miguel, and R. S. Winer. "Endogeneity in Brand Choice Models.” Management Science 45 (1999), 1324-1338.

Ward, Ronald W. and Richard L. Kilmer. The Citrus Industry: A Domestic and International Perspective. Ames, Iowa: Iowa State University Press, 1989.

Weiss, Yoram. "Introduction," in Optimal Pricing, Inflation, and the Cost of Price Adjustment, edited by Eytan Sheshinski and Yoram Weiss. Cambridge, MA: The MIT Press, 1993, 3-17. 


\section{Footnotes}

1. See, for example, Encaoua and Geroski (1984), Blinder, et al. (1998), Geroski (1992), and Levy and Young (2001).

2. The results for these ten products are available from the authors upon request.

3. This is different from the input-output structure of Gordon (1990) and Basu (1995). As Gordon (1990) suggests, the input-output view of the market is better suited for more aggregated and complex products produced using many inputs. In contrast, here we study individual products, and also the products themselves are simple, produced with few inputs.

4. The retail prices reflect retailer's coupons and discounts, but not manufacturer coupons, which are rarely used in this market. The wholesale prices do not include lumpy payments like slotting allowances which, according to the price manager of the chain, were not common in the orange juice category during the period covered in our study.

5. The use of nearest futures price as a proxy of the spot price means that once a month there may be a change from month $n$ contract to month $n+1$ contract. We adjust the series for storage and carrying cost to resolve this problem. We use the interest rate on 6-month treasury bill to compute the storage cost. Monthly carrying cost data are described in Florida Department of Citrus' (1994) Citrus Reference Book. The spot cost is divided by 1,600 to get a $\$ / o z$ price. The price quoted at New York Cotton Exchange is for orange concentrate level of $57^{\circ}$ Brix. A Brix is a temperature-adjusted measure of pound solids and sugar content in one gallon orange juice. The Brix level of frozen concentrated orange juice and refrigerated juice is $41.8^{\circ}$ and $11.7^{\circ}$, respectively. Therefore, we adjusted downwards the New York Cotton Exchange spot price to ensure identical quality of the orange juice at all levels of the channel.

6. Two aggregate demand shocks could affect the orange juice market: (i) the Kuwait War of January 17, 1991-February 27, 1991, and (ii) the July 1990-March 1991 recession. We, however, found no evidence of such effects on the orange juice market. 
7. Figure 2 displays the cost-price data for the Tropicana brand refrigerated orange juice, 96oz. Because of the difference in the Brix content of the frozen concentrated orange juice and refrigerated orange juice, we had to adjust the spot cost data downwards to ensure the equality in the Brix-adjusted quality of the orange juice prices plotted on Figure 2.

8. The frequent promotional activity visible in the retail and wholesale prices are standard practice for retailers of these and similar products (Levy et al., 1998). Its main reason is the competitive nature of the retail food industry.

9. Other stations do not keep records going so far back or do not have information readily available. Local radio stations do not have well-organized archives and so we could not get any information from them.

10.A "theme" is the most common unit of focus in content analysis (Holsti, 1969; and Kassarjian, 1977).

11.See Tse, Belk, and Zhou (1989) for recent examples of studies that use content analysis.

12.In Tables A1-A3 and A4-A6 of the appendix, we report the specific informational items we were able to find that relate to the first and second cost shocks, respectively. A list of all information sources consulted is provided at the end of the appendix.

13.The wholesale price decrease on the 8th week of the sample and its increase back to the original level by the 14th week seems to be of a promotional nature and is unrelated to the cost shock that occurred on the 15 th week, because, as mentioned in the text, that shock was unanticipated.

14.We should mention, however, that Müller (1999) examines in more detail the issue of asymmetric price adjustment to cost changes using a dataset from the same retailer, and finds mixed results for the orange juice category.

15.We should note a possible link between price rigidity and promotional activities. For example, in response to higher costs, a retailer may decrease the frequency of "sales" instead of increasing the price. A visual examination of Figure 1, however, reveals that the decrease in the frequency of sales in response to the second cost shock is no different from a similar decrease in the sales frequency in 
response to the first cost shock, if one considers the first six month from the time the shocks occur. The idea, nevertheless, seems interesting and could be fruitfully explored with a larger data set, perhaps as part of a study of non-price adjustment mechanisms.

16.We have also explored the effect of cost changes on wholesale and retail prices econometrically by estimating a VAR model incorporating the exogeneity assumptions discussed in section 2 as the identifying restrictions. We estimated the model for the September 7, 1989-May 16, 1991 and May 23, 1991-November 19, 1992 periods. The split point was selected based on a recursive estimation of the model along with Chow test statistics. In order to quantify the idea of dynamic price adjustment to cost changes, we computed the cumulative impulse response of price in dollars to one dollar shock in cost. The findings, which are not reported here to save space but are available upon request, are consistent with our interpretation of the cost-price data. Specifically, we find that the first sample period is characterized by higher price flexibility than the second. It should be noted, however, that these impulse responses represent the dynamic response of prices to average cost shocks, not to the two specific shocks we have focused on. But since the first cost shock is larger than the second, the average shock in the first sample is larger than the second and therefore, the econometric findings are consistent with our data interpretation.

17.The only commonality of the two shocks is that neither shock was anticipated, according to Ed Moore of the Florida Department of Citrus and John Attaway of the Florida Agricultural Statistics Service (personal communication).

18.These freezes are unpredictable until 2-3 days before the freeze, and even then its severity is unknown (Roll, 1984; and Baur and Orazem, 1994). According to John Attaway of the University of Florida Center for Citrus Research and Education (personal communication), Florida Department of Citrus defines as a "significant freeze" any freeze that results in a 25 percent of more decrease in crop. Indeed, as Table 1 indicates, the orange crop during the 1989-90 season was down by 24.8 percent and the yield was down by more than 26 percent.

19.United States Department of Agriculture is required to issue a monthly report of its Florida crop projections. The first report is released on the 2 nd week of October followed by monthly updates till July. Their goal is to help growers, processors, and other market participants to plan their future 
activities. The release of the United States Department of Agriculture orange crop reports is widely anticipated, especially the October report (Baur and Orazem, 1994) but its content is unknown. Since the effect of these projections on the frozen concentrated orange juice market can be dramatic, United States Department of Agriculture keeps them extremely secret until their release.

20.See also the July 1990 Florida Orange Crop Reports of the Florida Agricultural Statistics Service and the Florida Citrus Processors Association.

21.Despite a wide variation in shock persistence across industries and markets (Brunner, et al., 1983; Andersen, 1994; and Chirinko and Fazzari, 1994), it has not received as much attention in the empirical price rigidity literature as other factors like industry concentration, which according to Carlton (1989) is the most commonly cited reason for price rigidity. As Carlton (1989, p. 911) suggests, “... differences in market characteristics such as shock persistence may well be of more importance to macroeconomists than the effects of differences in concentration."

22. We cannot prove that market participants actually "collected and used" more information about the first cost shock than the second. We are only able to demonstrate that the market provided more information about the fist shock than the second. It should be noted also that it is impossible to know precisely what information is used by particular market participants. It is likely that all market participants are exposed to the information circulated by mass media such as radio, TV, and newspapers, regardless of their incentives. However, for some market participants the stakes are obviously higher, and therefore, they are likely to invest more resources in the relevant information gathering activity. Thus, we predict that spot and wholesale market participants who deal with large volumes and fluctuating market conditions in the frozen concentrated orange juice markets are more likely to gather the relevant information from specialized sources such as the United States Department of Agriculture reports, the Florida Department of Citrus reports, trade publications, etc. The retailers and their customers, on the other end of the channel, are least likely to invest in information gathering from any particular source because their stakes are smaller in this matter.

23.See also Caplin and Leahy (1995).

24.For example, the analysis conducted here could be fruitfully applied to larger scanner data sets such 
as the data sets used by Barsky, et al. (2002), Chen, Bergen, and Levy (2001) and Chevalier, et al. (2000). 


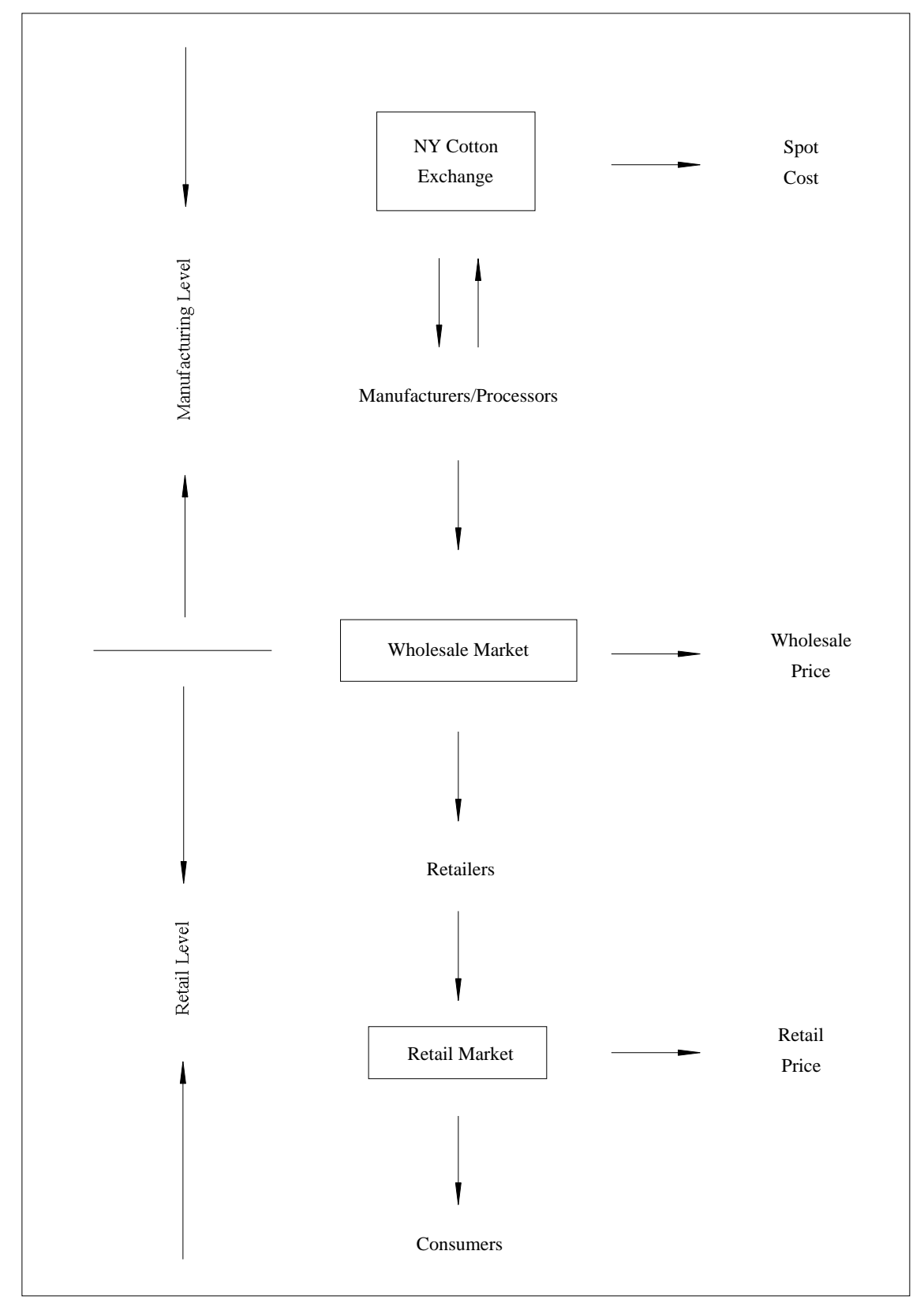

\section{CHART 1. Schematic Description of the Florida Frozen Concentrated Orange Juice Market}

Note: Chart 1 provides a simplified description of the organizational structure of the Florida orange juice market. Orange juice growers sell the fruit to orange juice manufacturers/processors who convert the oranges into frozen concentrate. There are two types of processors: one group of processors are privately owned and produce orange juice for private label. The other group of processors are owned by national orange juice manufacturers like Tropicana and Minute Maid, and they produce nationally branded products. The manufacturers/processors package and sell the concentrated juice to retailers, either in its frozen form or reconstituted from concentrate and packaged as refrigerated juice. Oranges are also sold for other uses such as for preparing freshly-squeezed juice, for table use, for producing food additives, and so forth through other channels of distribution. These additional uses and their associated channels are not shown on the chart since in this paper we only study the market for frozen concentrated and refrigerated (reconstituted from frozen concentrated) orange juice. See Ward and Kilmer (1989) for details. 


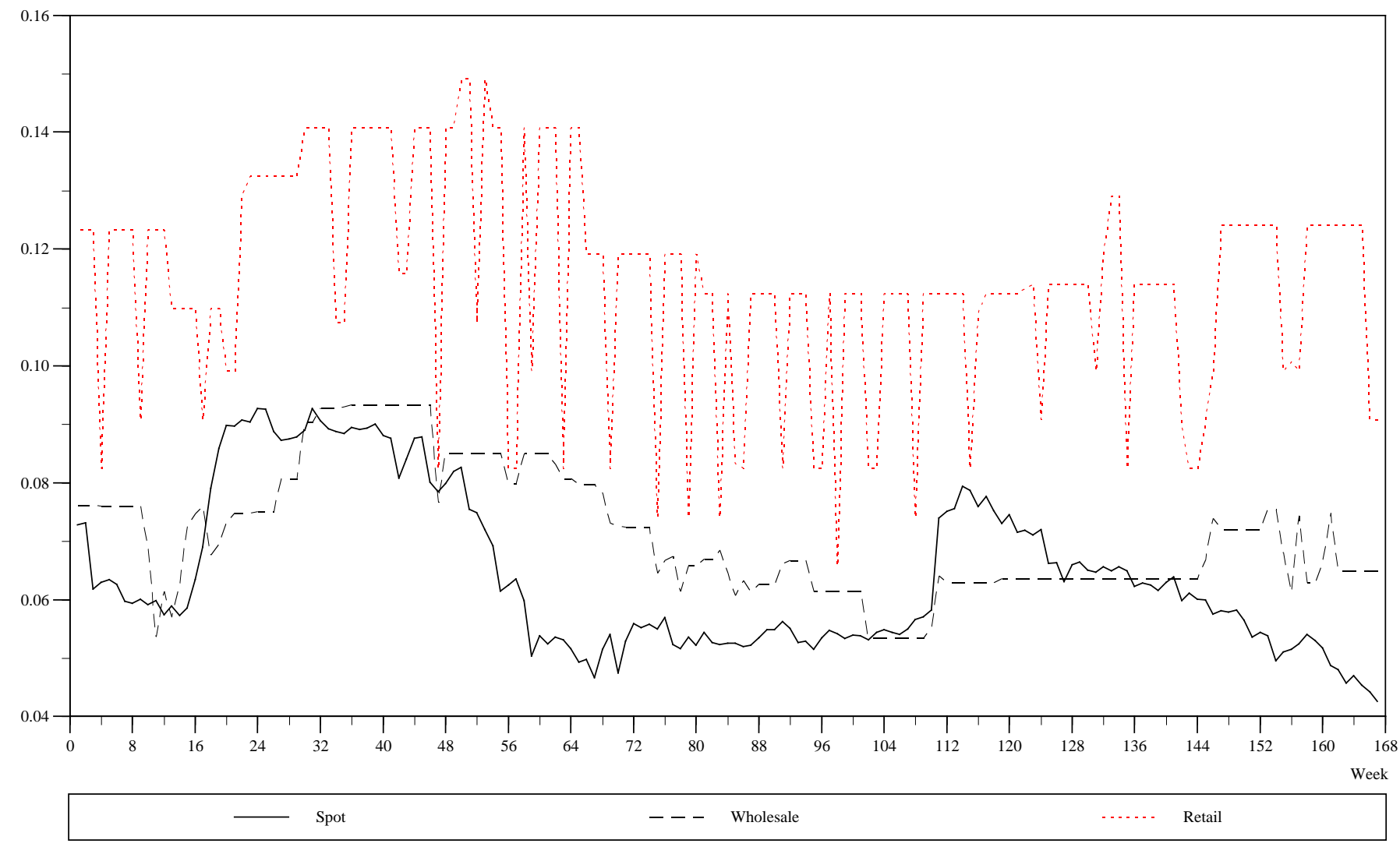

FIG. 1. Cost and Price Series of Frozen Concentrated Orange Juice, Store Brand, 12oz (dollars/oz) 


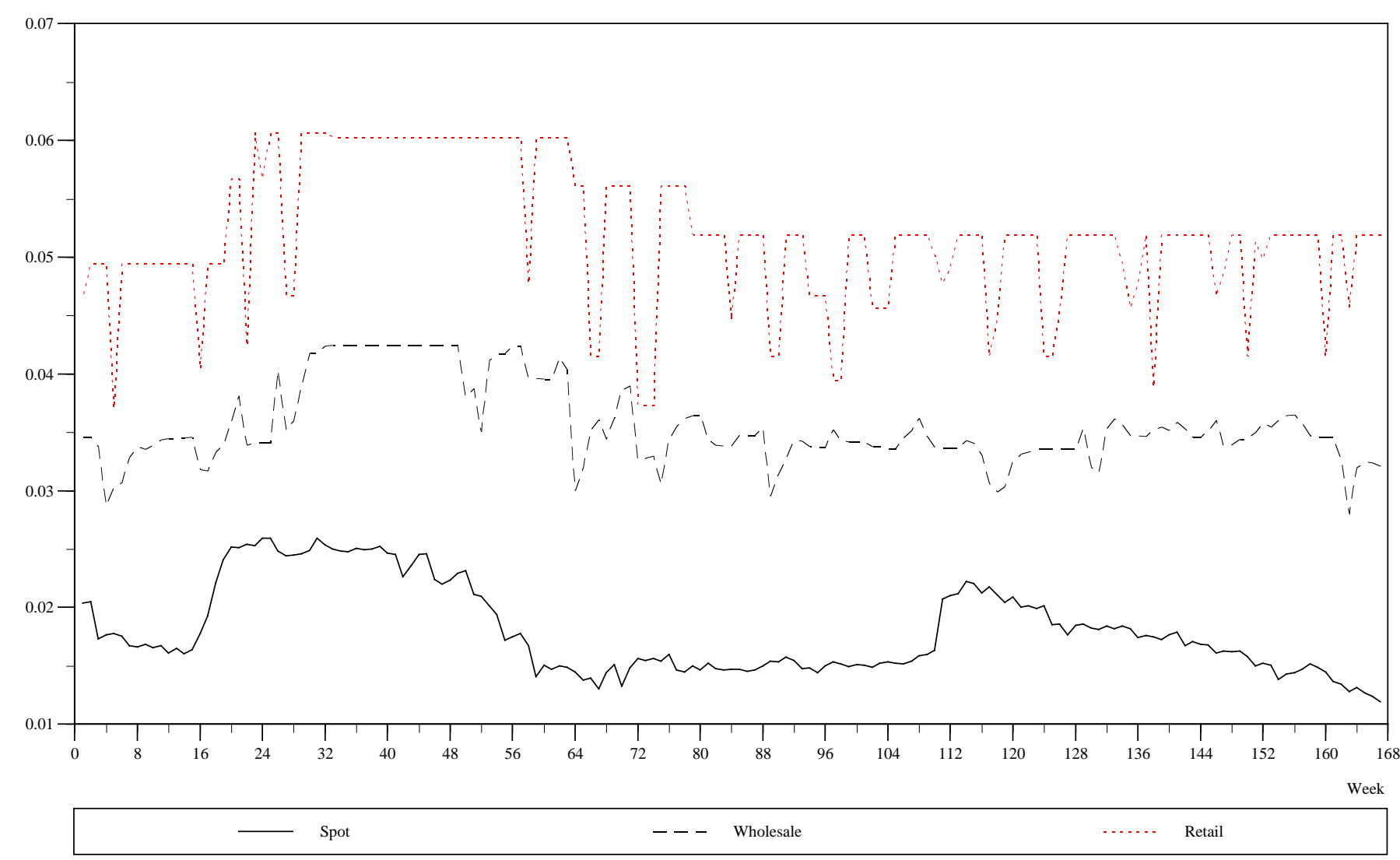

FIG. 2. Cost and Price Series of Refrigerated Orange Juice, Tropicana, 96oz (dollars/oz) 
TABLE 1

CROP, PRICE, AND YIELD OF FLORIDA ORANGES, 1988-93

\begin{tabular}{|c|c|c|c|c|c|}
\hline & \multicolumn{5}{|c|}{ Growing Season } \\
\hline & 1988-89 & $1989-90$ & 1990-91 & $1991-92$ & $1992-93$ \\
\hline Orange Crop (million box) $)^{\mathrm{a}}$ & 146.60 & 110.20 & 151.50 & 139.80 & 186.60 \\
\hline Florida Oranges Price (per box) $)^{b}$ & 7.61 & 10.31 & 8.46 & 8.52 & 3.80 \\
\hline Yield Per Acre (box)c & 377.00 & 276.00 & 360.00 & 315.00 & 381.00 \\
\hline
\end{tabular}

Notes: (a) 90 pound box; Source: Florida Department of Citrus (1994, p. 10).

(b)1 3/5 bushel box; Source: Florida Agricultural Statistics Service (1994, p. 14).

(c) 90 pound box; Source: Florida Agricultural Statistics Service (1994, p. 8). 
TABLE 2

USDA ESTIMATES OF FLORIDA FROZEN CONCENTRATED ORANGE JUICE GALLONSPER-BRIX YIELD

\begin{tabular}{lccccc}
\hline & \multicolumn{5}{c}{ Growing Season } \\
\hline Month & $1988-89$ & $1989-90$ & $1990-91$ & $1991-92$ & $1992-93$ \\
\hline October & 1.52 & 1.48 & 1.52 & 1.50 & 1.48 \\
November & 1.52 & 1.48 & 1.52 & 1.50 & 1.48 \\
December & 1.52 & 1.48 & 1.50 & 1.50 & 1.48 \\
January & 1.50 & 1.30 & 1.48 & 1.50 & 1.52 \\
February & 1.52 & 1.29 & 1.48 & 1.51 & 1.55 \\
March & 1.52 & 1.24 & 1.48 & 1.52 & 1.57 \\
April & 1.53 & 1.21 & 1.47 & 1.52 & 1.57 \\
May & 1.53 & 1.22 & 1.45 & 1.54 & 1.58 \\
June & 1.53 & 1.23 & 1.45 & 1.55 & 1.58 \\
July & 1.53 & 1.23 & 1.45 & 1.55 & 1.58 \\
\hline
\end{tabular}

Notes: Measurement units are $42^{\circ}$ Brix gallons.

Source: Florida Department of Citrus (1994, p. 15). 


\section{TABLE 3}

SUMMARY OF THE INFORMATION ON THE TWO COST SHOCKS

First Shock

December 23-24, 1989.

Date:

Cause:

A severe freeze.

Temperature:

Below $25^{\circ} \mathrm{F}$ for two days.

Damage to fruit:

Damage to trees:

Effect on crop:

Effect on yield:

Prices:

Print media:

TV Reports:

FDC \& USDA:

Emergency:
A portion of the fruit on trees is lost. ${ }^{a}$

About 20\% destroyed.

$24.8 \%$ decrease in orange crop.

$26.8 \%$ decrease in boxes/acre and $13.2 \%$

decrease in gallons/brix.

Stay high for about 28 weeks after the increase.

28 mentions ( 23 reports mention extensive damage to the citrus crop and the resulting price increase).

6 reports (WGN-Chicago and $\mathrm{CNN}$ ): all six discuss the severity of the damage.

5 reports: all predict low output and high price.

The freeze has been classified by Florida Department of

Citrus as one of the 9 major freezes over the last 40 years.

Governor of Florida declares the entire state a

disaster area and asks for Federal assistance.
Second Shock

October 13, 1991.

USDA's October 12 "shocking" forecast of $10 \%$ lower than last year's crop. The market expected $10 \%$ higher than last year's crop.

January 1992 temperature was below normal. Spring temperatures and rainfall were above normal. As a result, harvest began early and it was concluded earlier than normally.

No damage to fruit.

No damage to trees.

$7.7 \%$ decrease in orange crop.

$12.5 \%$ decrease in boxes/acre and $2.7 \%$ increase in gallons/brix.

Start to decline immediately after the increase.

17 mentions (11 reports mention price increase). But some suggest speculative and psychological reasons for it. Six reports in January 1992 mention orange juice prices actually coming down because the fear of freeze seem unwarranted.

No TV report on price increase. The only report (on CNN, December $24,1991)$ actually mentioned increased orange crop expectations.

One report: lower-than-expected 1991-92 crop was an aberration and did not change their forecast of record crops in the future.

None.

(a) About $90 \%$ of the fruit was still on trees when the freeze occurred. 


\section{List of Information Sources Consulted}

\section{Governmental Sources}

Agricultural Prices, United States Department of Agriculture

Agricultural Statistics, United States Department of Agriculture

Citrus Outlook, Economic Research Department, Florida Department of Citrus

Citrus Reference Book, Economic and Market Research Department, Florida Department of Citrus

Crop Production, United States Department of Agriculture

Fruit and Tree Nuts Situation and Outlook Report, United States Department of Agriculture

Producer Price Indexes, United States Bureau of Labor Statistics

In addition we talked to numerous individuals and experts from:

Florida Department of Citrus

University of Florida Center for Citrus Research and Education

Florida Agricultural Statistics Service

New York Cotton Exchange

Florida Citrus Commission

Produce Manufacturing Association

Florida Department of Agriculture and Consumer Services

Florida Department of Citrus, Economic and Marketing Research Department

\section{Trade Publications}

American Fruit Grower, American Vegetable Grower, California Grower, California Food, Citrus and Vegetable Magazine, Costal Grower, Eurofruit, Feedstuffs, Florida Shipper, Food

Technology, Foreign Trade, Fresh Cut, Fruit and Tropical Products, FPFC Digest, Good

Fruit Grower, Grocery Marketing, ID/The Voice of Foodservice, Distribution IGA, Grocergram, International Fruit, World Hortscience, International Produce Journal, Michigan Food News, Mushroom News, The Packer, The Produce News, Potato Grower, Produce Business, Progressive Grocer, Refrigerated Transporter, Restaurant Business, Restaurant Hospitality, Restaurants and Institutions, Restaurant News, Supermarket Business, Supermarket News, and Veggie Life.

\section{Newspapers/Popular Magazines}

Chicago Tribune

The New York Times

Time

USA Today

The Wall Street Journal

\section{Television Stations (in Chicago)}

WLS [ABC]

WMAQ [NBC]

WBBM [CBS]

WGN-Channel 9, Chicago

$\mathrm{CNN}$

\section{Radio Stations (in Chicago)}

NPR

WMAQ

WBBM 


\section{APPENDIX}

\section{INFORMATION ON THE TWO COST SHOCKS}

\section{TABLE A1}

INFORMATION ON THE FIRST COST SHOCK: NEWSPAPER AND OTHER PRINT MEDIA REPORTS

\begin{tabular}{|c|c|c|c|c|}
\hline Date & Source & Section & Page & Summary of the Information \\
\hline December 20, 1989 & Wall Street Journal & Money & 16 & Freeze severely damages orange crop in Florida. \\
\hline December 20, 1989 & New York Times & Business & 16 & Orange juice price up from fear of freeze. \\
\hline December 21, 1989 & New York Times & Business & 14 & Orange juice price up from fear of freeze. \\
\hline December 22, 1989 & New York Times & Business & 14 & Orange juice price up, frigid weather forecast. \\
\hline December 23, 1989 & New York Times & Business & 46 & Orange juice price drops sharply, skittish players take profit before holidays. \\
\hline December 24, 1989 & Chicago Tribune & Business & 4 & Orange juice future prices soar as cold threatens Florida. \\
\hline December 24, 1989 & New York Times & Business & 12 & Orange juice prices up with prospect of freeze. \\
\hline December 27, 1989 & Chicago Tribune & Business & 1 & Citrus growers optimistic little harm from freeze. \\
\hline December 29, 1989 & New York Times & Business & 1 & $\begin{array}{l}\text { Florida Governor declared the entire state a disaster area due to the impact of the freeze on } \\
\text { the orange crop. Has sought Federal aid and low-interest loans for farmers. }\end{array}$ \\
\hline December 29, 1989 & New York Times & Business & 12 & Brazil suspends exports sending prices up. \\
\hline December 29, 1989 & Wall Street Journal & Money & 12 & Florida's governor declares the entire state a disaster area following freeze. \\
\hline December 30, 1989 & New York Times & Business & 41 & $\begin{array}{l}\text { Orange juice prices up as Florida faces warm weather (means oranges fall from trees and } \\
\text { rot). }\end{array}$ \\
\hline December 31, 1989 & New York Times & Business & 12 & Brazil suspends exports to assess price situation. \\
\hline January 3, 1990 & New York Times & Business & 1 & Orange juice prices rise as producers raise prices. \\
\hline January 6, 1990 & New York Times & Business & 42 & Orange juice price soars with new concerns about frost. \\
\hline January 8, 1990 & Time & & 59 & Citrus production severely reduced by cold. \\
\hline
\end{tabular}


TABLE A1

INFORMATION ON THE FIRST COST SHOCK: NEWSPAPER AND OTHER PRINT MEDIA REPORTS (CONT.)

\begin{tabular}{|c|c|c|c|c|}
\hline Date & Source & Section & Page & Summary of the Information \\
\hline January 12,1990 & Chicago Tribune & Business & 1 & Sharp cutback on orange crop estimates. \\
\hline January 12,1990 & USA Today & & $1 \mathrm{~B}$ & Citrus production off $25 \%$ for $1989-90$. \\
\hline January 13,1990 & Chicago Tribune & Business & 7 & $\begin{array}{l}\text { Orange juice futures up sharply as first estimates indicate that losses were as severe as } \\
\text { expected. }\end{array}$ \\
\hline January 17,1990 & New York Times & Business & 18 & Orange juice prices up on reports that Brazil may not meet demand. \\
\hline January 23, 1990 & New York Times & Business & 17 & Orange juice prices up to record high with reports of damage higher than expected. \\
\hline January 25,1990 & New York Times & Business & 19 & Orange juice prices down, strongest since freeze. \\
\hline January 25, 1990 & New York Times & $\mathrm{C}$ & 7 & $\begin{array}{l}\text { Orange juice is going to get more expensive, says Dan Shafer of Minute Maid. Crop } \\
\text { reduced } 30 \% \text { by freeze. Brazil price } 132-192 \text { per pound this week. Dr. Bob Behr of } \\
\text { Florida Department of Citrus says price increase will not be felt until late February, } \\
\text { prices should go up } 20 \% \text {, yearly average of up only } 8.5 \% \text {. }\end{array}$ \\
\hline February 2, 1990 & New York Times & Business & 13 & Orange juice prices down, retreating from December highs. \\
\hline February 3, 1990 & Packer & & 7A & December freeze will raise Florida orange juice prices in 1989-90. \\
\hline February 8, 1990 & New York Times & Business & 21 & Orange juice prices up, freeze heading South? \\
\hline February 10, 1990 & New York Times & Business & 42 & Orange juice prices down, actual production up over January estimates. \\
\hline March 8, 1990 & New York Times & Business & 19 & $\begin{array}{l}\text { Orange juice prices up on speculation that Department of Agriculture would revise crop } \\
\text { estimate downward. (The report came out on March 9, 1990.) }\end{array}$ \\
\hline
\end{tabular}




\section{TABLE A2}

INFORMATION ON THE FIRST COST SHOCK: TELEVISION REPORTS

\begin{tabular}{|c|c|c|c|c|}
\hline Date & Source & Reporter & Report Length & Summary of the Information \\
\hline December 23, 1989 & $\begin{array}{l}\text { WGN Channel 9, } \\
\text { Chicago }\end{array}$ & Tony Noce & $1: 27$ minutes & $\begin{array}{l}\text { Discussing the Florida freeze and its disastrous impact on the } \\
\text { Florida citrus crop. }\end{array}$ \\
\hline December 22, 1989 & $C N N$ & Chris Abel & 2:01 minutes & Discussing the disastrous impact of the freeze on citrus growers. \\
\hline December 23, 1989 & $C N N$ & Dan Ronin & 2:01 minutes & $\begin{array}{l}\text { Discussing the effect of cold Florida weather on orange juice, } \\
\text { travel and other effects. }\end{array}$ \\
\hline December 26, 1989 & $C N N$ & Grant Perry & $1: 43$ minutes & $\begin{array}{l}\text { Discussing the damaged orange crop due to freeze and reduced } \\
\text { crop prospects. }\end{array}$ \\
\hline January 22, 1990 & $C N N$ & John Zarrella & 1:52 minutes & Discussing the impact of freeze on the orange crops in Florida. \\
\hline
\end{tabular}




\section{TABLE A3 \\ INFORMATION ON THE FIRST COST SHOCK: FLORIDA DEPARTMENT OF CITRUS' ECONOMIC RESEARCH DEPARTMENT AND US DEPARTMENT OF AGRICULTURE REPORTS}

\begin{tabular}{|c|c|c|c|}
\hline Date & Source & Page & Summary of the Information \\
\hline \multirow[t]{5}{*}{ October 25,1989} & Citrus Outlook & 1 & United States Department of Agriculture's October 12, 1989 crop forecast placed \\
\hline & & & Florida's 1989-90 round-orange and Temple production at 133.0 million boxes, 17.3 \\
\hline & & & million lower than production in 1988-89. The reduced crop prospects stem from the \\
\hline & & & effects of a February [1989] freeze which hurt a significant amount of early bloom and \\
\hline & & & reduced the amount of fruit set. \\
\hline
\end{tabular}

October 25, 1989

Citrus Outlook

4

October 25, 1989

Citrus Outlook

United States Department

of Agriculture Citrus Estimate,

Report No. 89/90-4
United States per capita orange-juice consumption has averaged 5.0 SSE gallons during this decade. The annual figures for the 1980's, as reported by Florida Department Citrus (1994, p. 60), tend to fluctuate around this average.

United States Department of Agriculture's October 12, 1989 crop forecast estimates the 1989-90 juice yield at $1.48^{\circ}$ Brix gallons per box, 3.3 percent lower than in 1988-89.

Estimates for 1989-90 Florida Oranges were revised downwards in January to 157,950,000 boxes from October and December 1989 estimates of 194,350,000 boxes. 


\section{TABLE A4}

INFORMATION ON THE SECOND COST SHOCK: NEWSPAPER AND OTHER PRINT MEDIA REPORTS

\begin{tabular}{|c|c|c|c|c|}
\hline Date & Source & Section & Page & Summary of the Information \\
\hline October 3, 1991 & New York Times & Business & 17 & Orange juice price up. \\
\hline October 8, 1991 & New York Times & Business & 20 & Orange juice price up after United States Department of Agriculture forecast. \\
\hline October 14, 1991 & Wall Street Journal & Money & 12 & $\begin{array}{l}\text { Orange juice price up after United States Department of Agriculture forecast of a } 10 \% \\
\text { smaller crop than the previous year, when industry analysts expected } 10 \% \text { larger crop. }\end{array}$ \\
\hline October 16, 1991 & New York Times & Business & 17 & $\begin{array}{l}\text { Orange juice price up as United States Department of Agriculture predicts 1991-92 } \\
\text { production. }\end{array}$ \\
\hline October 16, 1991 & New York Times & Business & 20 & Orange juice price up fifth straight day. \\
\hline October 25,1991 & New York Times & Business & 13 & Orange juice price up with speculation. \\
\hline October 31, 1991 & New York Times & Business & 1 & Orange juice price up sharply in trading after two days of lower prices. \\
\hline November 5, 1991 & New York Times & Business & 22 & Orange juice price up, though cold weather not to effect Florida. \\
\hline November 6, 1991 & New York Times & Business & 16 & Orange juice price up, Brazil and U.S. processors raise prices. \\
\hline November 7, 1991 & Wall Street Journal & Money & 16 & $\begin{array}{l}\text { Orange juice prices up, because Brazil and U.S. processors raise prices. The cold in } \\
\text { North Florida is not expected to effect the orange crop, but the cold spell is having a } \\
\text { psychological effect on the market. }\end{array}$ \\
\hline November 12, 1991 & New York Times & Business & 21 & Orange juice price up sharply after two down days. \\
\hline January 7, 1992 & New York Times & Business & 20 & Orange juice price down. \\
\hline January 8, 1992 & New York Times & Business & 14 & Orange juice price down second consecutive day. \\
\hline January 18, 1992 & New York Times & Business & 45 & Orange juice price down, reversed fears on cold weather. \\
\hline January 21, 1992 & New York Times & Business & 17 & Orange juice price down fifth day. \\
\hline January 22, 1992 & New York Times & Business & 13 & Orange juice price down sixth day, fear of freeze abates. \\
\hline January 25, 1992 & New York Times & Business & 45 & Orange juice price down, rumors Brazil crop up next year. \\
\hline
\end{tabular}




\section{TABLE A5}

INFORMATION ON THE SECOND COST SHOCK: TELEVISION REPORTS

\begin{tabular}{|c|c|c|c|c|}
\hline Date & Source & Reporter & Report Length & Summary of the Information \\
\hline December 24, 1991 & $C N N$ & Robert Vito & $1: 53$ minutes & $\begin{array}{l}\text { Reporting that orange crops had picked up after previous year's } \\
\text { weak crop. }\end{array}$ \\
\hline
\end{tabular}


TABLE A6

INFORMATION ON THE SECOND COST SHOCK: FLORIDA DEPARTMENT OF CITRUS' ECONOMIC RESEARCH DEPARTMENT AND US DEPARTMENT OF AGRICULTURE REPORTS

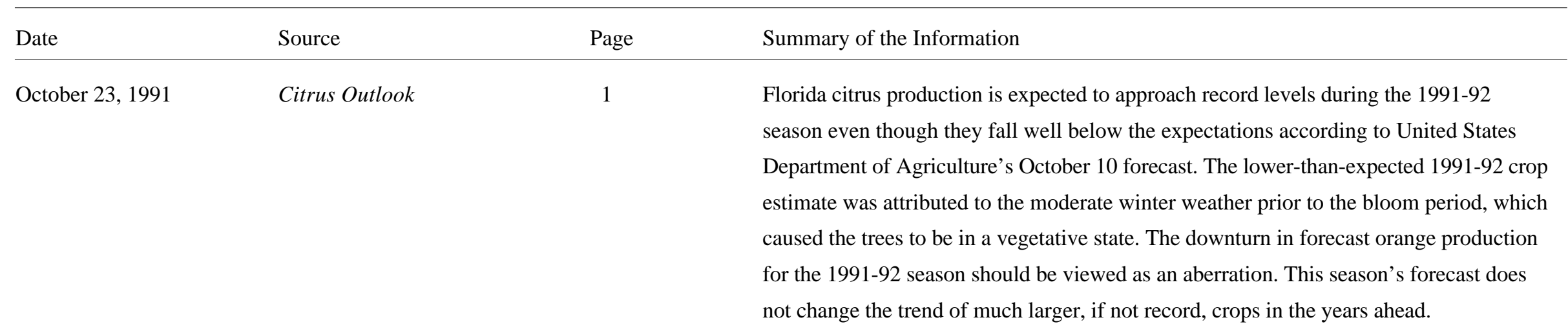

